Special Issue of the 8th International Advances in Applied Physics and Materials Science Congress (APMAS 2018)

\title{
Wind Tunnel Experiments and CFD Simulations for Gable-Roof Buildings with Different Roof Slopes
}

\begin{abstract}
M. AtmaCA*
Department of Mechanical Engineering, Marmara University Faculty of Technology, Istanbul, 34722, Turkey

Wind tunnel experiments and numerical simulations (CFD) were carried out on gable-roof buildings with different roof slopes. Experimental studies were implemented in wind tunnel on roof models with three different slopes $\left(\alpha=10^{\circ}, \alpha=20^{\circ}\right.$, and $\left.\alpha=30^{\circ}\right)$. Database was created around the building for time-averaged velocity, turbulent kinetic energy, and pressure coefficient. Analyses were implemented for investigations of grid number effect and turbulence model effect for the $\alpha=20^{\circ}$ roof slope model. Grid determination and turbulence models were investigated and validated by comparing the results of the computational fluid dynamics simulations with the experimental data for all the roof slopes. Generally, the numerical results showed compatibility with the experimental results despite some differences. Eventually, the effect of the roof slope on the gable-roof buildings were expressed using the computational fluid dynamics results.
\end{abstract}

DOI: 10.12693/APhysPolA.135.690

PACS/topics: gable roof, CFD, simulation, wind tunnel experiment

\section{Introduction}

Roof's slope has an important influence on the flow environment surrounding a building [1]. Wind-related roof damage or collapse can cause life and property loss, and thus wind load is one of the most important parameters in roof design. However, the effects of wind on roofs vary according to several factors, including wind magnitude and direction, and roof slope and geometry (e.g., gabled, tower type). Wind load is typically determined by measuring wind pressure at various points of roof models under different wind conditions in a wind tunnel. However, this technique is time-consuming, difficult, and expensive. New advances in software development, however, have made it possible to model wind load, and thereby enable designers and researchers to assess structures of various designs under various wind conditions to choose an optimal design before beginning production. The influence of roof lopes on the buildings has been examined both experimentally and numerically in many studies [2-16].

In this study, gable roof buildings which have different slopes were investigated experimentally and numerically. CFD simulations were performed and compared with experimental results. Finally, the effect of the roof slope on the building was clarified using the CFD results.

\section{Experimental setup and measurements}

Gabled roofs with rectangular closed surfaces and triangle shield sides are commonly preferred in construction, because of their simplicity and relatively lower cost.

\footnotetext{
*e-mail: matmaca@marmara.edu.tr
}

Therefore, that basic design was used in wind tunnel experiments to take pressure measurements (Fig. 1). In the figure, surface $E$ represents the windward roof surface, or that which is facing the wind, and surface $F$ is the leeward roof surface. The other dimensions are as follows: length $d=135 \mathrm{~mm}$, width $s=135 \mathrm{~mm}$, height $h=75 \mathrm{~mm} ; \Phi$ denotes wind direction angle, and $\alpha$ depicts roof angle. Gable roofs are defined according to windward and leeward slope angles, which are $\alpha_{1}$ and $\alpha_{2}$, respectively.

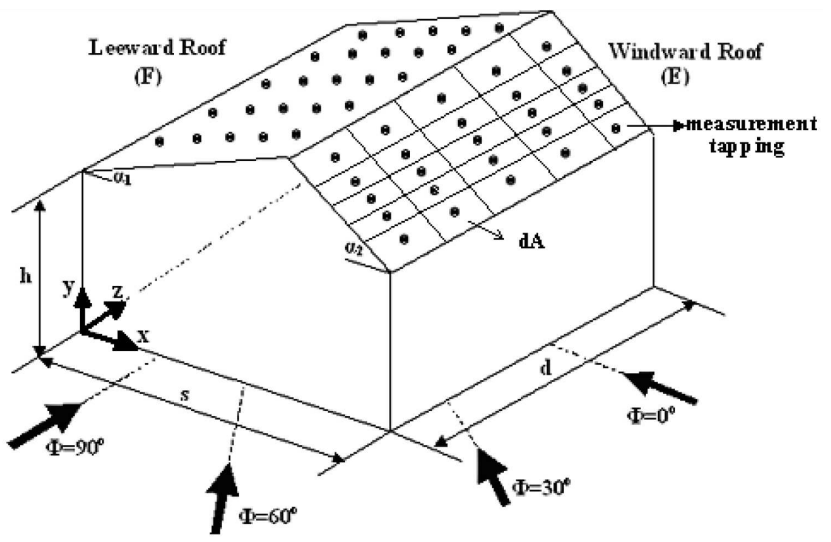

Fig. 1. Dimensions of experimental roof model and measurement points.

Experiments were performed in a suction wind tunnel. In all cases, pressure measurements were repeated from one side to the center of the building. Fifty sensors were attached to the surface of the model building, and then hoses (similar to those used by Stathopoulos and Saathoff [17]; internal diameter of $1.5 \mathrm{~mm}$, length of $600 \mathrm{~mm}$ ) that delivered air to the model were attached to the sensors. After measurements were taken, the wind load of the roof was converted to analog signals by the pressure sensors using an RXLdp Ashcroft transmitter 
at a range of $0-10$ mbar. These analog signals were in turn converted to numerical values, and then read by a computer.

Then pressure coefficients $\left(C_{p}\right)$, which account for variation in pressure and suction on vertical, horizontal, and inclined surfaces, were calculated as Eq. (1) [18, 19]:

$$
C_{p}=\frac{P-P_{0}}{\frac{1}{2} \rho V^{2}},
$$

where $P$ is static pressure at a point on the roof model, $P_{0}$ is uniform flow static pressure in the test section (at velocity $V), \rho$ is the density of air, and $V$ is velocity of uniform flow. Through cross-section measurements were taken with the hot-wire probe from 10 points were found in accordance with standard and mean velocity. The flow rate was calculated by multiplying the flow crosssectional area and mean velocity.

Special care was taken to minimize the error by making sure that the pipe was clamped down firmly and the Pitot tube was positioned so that its tip saw normal flow of air at every measurement. The measurement was taken by teams of two, so as to reduce the precision error.

The free stream velocity in the central point of the test section was assumed to be the best measure of the free stream velocity, as the region in the test section would have the least amount of turbulence. Taking this central velocity as the best measured value, it was used to analyse the values of free stream velocity across the crosssection of the test section.

Mean velocities were measured throughout a vertical line on the centre. Reference velocity was taken as $10 \mathrm{~m} / \mathrm{s}$ at the centre of test section of wind tunnel. Power law is given in the following Eq. (2). It gives velocity distribution

$$
\frac{U(z)}{U\left(z_{g}\right)}=\left(\frac{z}{z_{g}}\right)^{\alpha}
$$

In this experimental study, the exponent $\alpha$ was found as 0.25 . This is suitable value under neutral stability conditions, it is approximately between 0.23 and 0.28 [17].

\section{Numerical methods}

The FLUENT, which is commercial program, is used to analyse the flow in the numerical model. Finite volume method discretized the governing equations [20].

\subsection{Grid-sensitivity analysis}

Because mesh number affects both the efficiency and accuracy of CFD simulations, mesh refinement effects were first examined for different element numbers. Analysis was performed according to three grid cells. These grid cells are about 1,125,000 grid cells (coarser grid), 2,560,000 grid cells and 3,500,000 grid cells (finer grid). The differences in the overall pressure coefficient distribution between last two grid cells are around 3\%. Thus, considering both the computational time cost and solution precisions the second grid cells $(2,560,000)$ is taken for the whole computation. The free exit boundary conditions were as follows: the diffusion flow of all flow variables perpendicular to the exit plane were assumed to be zero, and exit velocity and pressure were assumed to be fully developed flow. The free-slip restrictions of computational space on the side and top surfaces were as follows: the normal gradients of all normal velocity ingredients, and all velocity ingredients were assumed to be zero.

\subsection{Influence of turbulence models}

Three turbulence models were tested. These models are the standard $k-\varepsilon$, the RNG $k-\varepsilon$, and the realizable $k$ $\varepsilon$. It was discretized transport equations using a secondorder upwind scheme. Second order scheme was accepted for pressure interpolation. It was used the simple algorithm for pressure-velocity coupling. Based on all of the above results, the essential components of the optimal model for estimating wind load were thus the following: CFD simulation using the ANSYS-Fluent software with RNG $k-\varepsilon$ turbulence model.

\subsection{Prediction of pressure coefficients}

Figure 2 shows the contours of the pressure coefficients, on the roof surfaces of the buildings with three different roof slopes. Apparently, the reference pressure has a considerable influence on the pressure coefficient. The reference pressure position is taken to be the same in wind tunnel experiments.

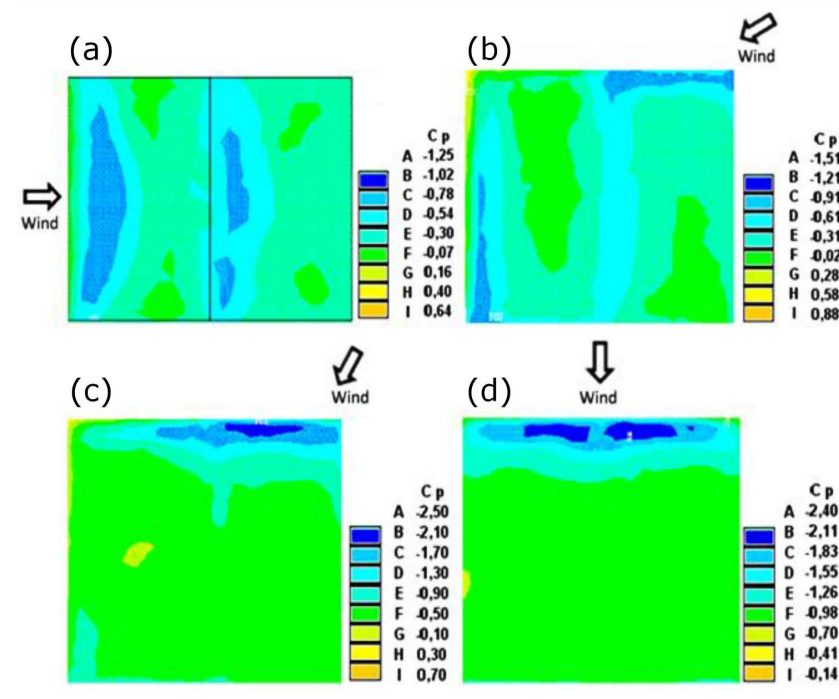

Fig. 2. Pressure coefficient on the roof surfaces with $\alpha=10^{\circ}$ slopes for $\Phi=0^{\circ}, \Phi=30^{\circ} \Phi=60^{\circ}$ and $\Phi=90^{\circ}$.

As can be seen from Fig. $2 \mathrm{a}-\mathrm{d}$, at an $\alpha=10^{\circ}$ roof slope, critical pressure coefficients occur on the windward side of the roof and near the ridges for a wind direction angle of $\Phi=0^{\circ}$, on the windward and leeward side of the roof for a wind direction angle of $\Phi=30^{\circ}$, on the leeward side of the roof for a wind direction angle of $\Phi=60^{\circ}$, windward side of the roof for a wind direction angle of $\Phi=90^{\circ}$, respectively. 
As can be seen from Fig. $3 \mathrm{a}-\mathrm{d}$, at an $\alpha=20^{\circ}$ roof slope, critical pressure coefficients occur near the ridges for a wind direction angle of $\Phi=0^{\circ}$, on the leeward side of the roof and near the ridges for a wind direction angle of $\Phi=30^{\circ}$, on the leeward side of the roof for a wind direction angle of $\Phi=60^{\circ}$, windward side of the roof for a wind direction angle of $\Phi=90^{\circ}$, respectively.

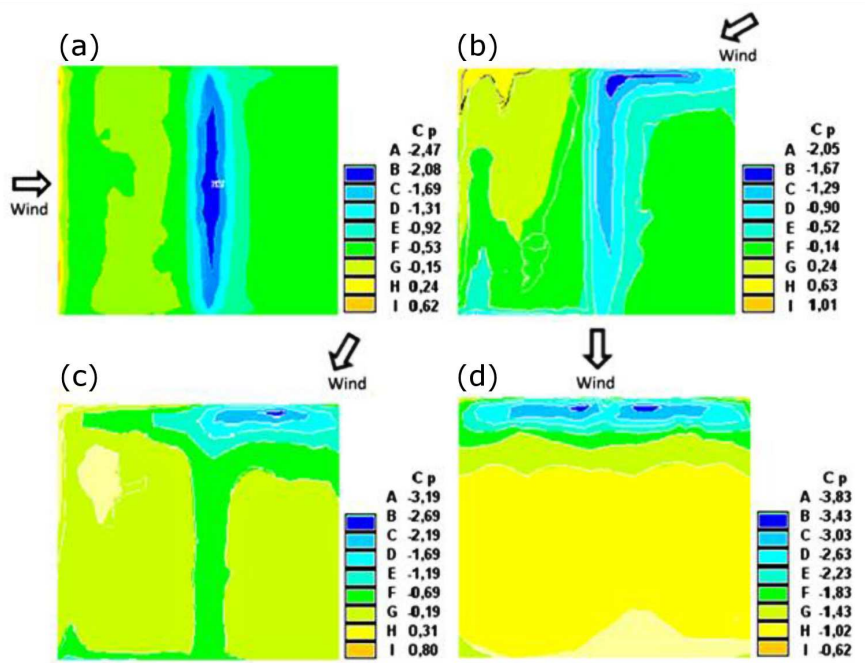

Fig. 3. As in Fig. 2, but with $\alpha=20^{\circ}$.

As can be seen from Fig. $4 \mathrm{a}-\mathrm{d}$, at $\alpha=30^{\circ}$ roof slope, critical pressure coefficients occur on the windward side of the roof and near the ridges for a wind direction angle of $\Phi=0^{\circ}$, on the leeward side of the roof and corner side surface for a wind direction angle of $\Phi=30^{\circ}$, on the corner side surface of windward side of the roof and on the side surface of leeward side of the roof for a wind direction angle of $\Phi=60^{\circ}$, on the side surfaces of the roof for a wind direction angle of $\Phi=90^{\circ}$, respectively.

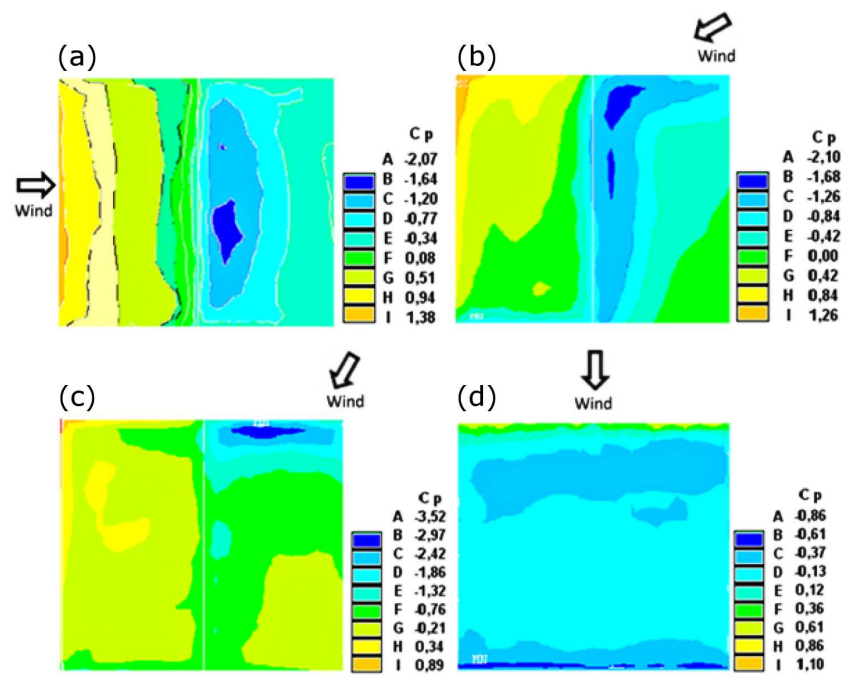

Fig. 4. As in Fig. 2, but with $\alpha=30^{\circ}$.

\section{Conclusions}

In this study, wind tunnel experiments and CFD simulations were implemented for gable roof buildings. Gable roofs have different roof slopes $\left(10^{\circ}, 20^{\circ}\right.$, and $\left.30^{\circ}\right)$. The following results were obtained.

- The differences are quite small between three turbulence models. But the RNG $k-\varepsilon$ turbulence model gave slightly better results than the other models (standard $k-\varepsilon$, realizable $k-\varepsilon$ ).

- Generally, numerical results agreed well with experimental data for the velocity despite some differences. The reason for these differences are fluctuations. Vortex shedding behind the ridge formed large-scale transient fluctuations. Thus, steady Reynolds-averaged Navier-Stokes (steady RANS) cannot be reproduced.

- The pressure coefficients $C_{p}$ are generally well reproduced by the CFD analyses. But negative peak value of $C_{P}$ near the separation region overestimated near the ridge for roof slopes (especially 200 and $\left.30^{\circ}\right)$.

- The separation flow at the ridge and the recirculation flow behind the building become larger as the roof slope becomes steeper.

- As roof slope increase, mean pressure changes from a negative to a positive value on the windward for a wind direction angle of $\Phi=0^{\circ}, \Phi=30^{\circ}$, and $\Phi=60^{\circ}$.

- Mean negative pressures occurring on the leeward side of the roof were greater than on the windward side of the roof.

- The lowest negative pressures at all of roof slopes occur for a wind direction angle of $\Phi=90^{\circ}$.

\section{References}

[1] Y. Tominaga, S. Akabayashi, T. Kitahara, Y. Arinami, Build. Environ. 84, 204 (2015).

[2] G.M. Richardson, D. Surry, J. Wind Eng. Industr. Aerodynam. 38, 249 (1991).

[3] M. Kanda, E. Maruta, J. Wind Eng. Industr. Aerodynam. 50, 173 (1993).

[4] T. Stathopoulos, K. Wang, H. Wu, Wind Struct. 4, 119 (2001).

[5] S. Rafailidis, Bound Layer Meteorol. 85, 255 (1997).

[6] P.K. Klein, E.J. Plate, Atmosph. Environ. 33, 3973 (1999).

[7] P.K. Klein, R. Berkowicz, R. Britter, Meteorol. Atmosph. Phys. 87, 121 (2004).

[8] Y. Huang, X. Hu, N. Zeng, Build Environ. 44, 2335 (2009). 
[9] Y. Takano, P. Moonen, J. Wind Eng. Industr. Aerodynam. 123, 107 (2013).

[10] A. Shklyar, A. Arbel, J. Wind Eng. Industr. Aerodynam. 92, 1039 (2004).

[11] J. Kindangen, G. Krauss, P. Depecker, Build. Environ. 32, 1 (1997).

[12] B.E. Lee, R.A. Evans, Build. Environ. 19, 235 (1984).

[13] P.J. Oliveira, B.A. Younis, J. Wind Eng. Industr. Aerodynam. 86, 203 (2000).

[14] P.M. Briggen, B. Blocken, H.L. Schellen, Build. Environ. 44, 1675 (2009).
[15] T.V. Hooff, B. Blocken, M.V. Harten, Build. Environ. 46, 22 (2011)

[16] T. Kobayashi, T. Chikamoto, K. Osada, Build. Environ. 63, 20 (2013).

[17] T. Stathopoulos, P. Saathoff, J. Wind Eng. Industr. Aerodynam. 38, 273 (1991).

[18] S. Reichrth, T.W. Davies, J. Wind Eng. Industr. Aerodynam. 90, 139 (2002).

[19] M. Kazakevitch, J. Wind Eng. Industr. Aerodynam. 77, 157 (1998).

[20] M. Atmaca, İ. Girgin, C. Ezgi, Int. J. Hydrogen Energy 41, 6004 (2016). 